\title{
Growth Responses of Zoysia spp. under Tree Shade in the Midwestern United States
}

\author{
Kenton W. Peterson ${ }^{1}$, Jack D. Fry ${ }^{2}$, and Dale J. Bremer \\ Department of Horticulture, Forestry \& Recreation Resources, Kansas State \\ University, 2021 Throckmorton Plant Science Center, Manhattan, KS 66506
}

Additional index words. zoysiagrass, Zoysia japonica, Zoysia matrella, Zoysia pacifica

\begin{abstract}
Meyer' zoysiagrass (Zoysia japonica Steudel) is commonly planted on home lawns and golf courses in the transition zone; however, poor shade tolerance limits its widespread use. This study was conducted to determine changes and differences in growth among selected Zoysia cultivars and progeny under a natural shade environment over a 3-year period in the transition zone. The study was initiated in June 2010 at the Rocky Ford Turfgrass Research Center in Manhattan, KS. Soil type was a Chase silt loam (fine, montmorillonitic, mesic, Aquic, Argiudoll). Zoysia genotypes were sodded in $0.37-\mathrm{m}^{2}$ plots and arranged in a randomized complete block with five replications under silver maple (Acer saccharinum L.) shade that resulted in a $91 \%$ reduction in photosynthetically active radiation $(P A R)$. Genotypes included 'Zorro' $[Z$. matrella $(\mathrm{L})$. Merrill], 'Emerald' [Z. japonica $\times$ Z. pacifica (Goudswaard) Hotta \& Kuroki], 'Meyer', Chinese Common (Z. japonica), and experimental progeny Exp1 (Z. matrella $\times Z$. japonica), and Exp2 and Exp3 [(Z. japonica $\times Z$. pacifica $) \times Z$. japonica]. 'Zorro' and 'Emerald' experienced winter injury, which negatively affected their performance. Tiller numbers decreased 47\% in 'Meyer' from June 2010 to June 2012, but declines in $[(Z$. japonica $\times Z$. pacifica $) \times Z$. japonica $]$ progeny were only $1 \%$ for Exp2 and $27 \%$ for Exp3, and both Exp2 and Exp3 maintained high percent green cover throughout the study. In general, by the third year of evaluation, progeny of $[(Z$.japonica $\times Z$. pacifica $) \times$ $Z$. japonica] had higher quality ratings and higher tiller numbers than 'Meyer' and may provide more shade-tolerant cultivar choices for transition zone turf managers.
\end{abstract}

Shade stress is a problem affecting the quality of an estimated $20 \%$ to $25 \%$ of all turfs (Beard, 1973; Dudeck and Peacock, 1992). Shading reduces incident solar radiation and alters the microclimate in which the turf grows (Beard, 1997). Turfgrass grown under shade suffers from reduced photosynthesis (Dudeck and Peacock, 1992; Qian et al., 1998), lower carbohydrate reserves (Atkinson et al., 2012; Bell and Danneberger, 1999; Burton et al., 1959; Qian et al., 1998), and reduced tillering (Ervin et al., 2002; Okeyo et al., 2011a; Qian et al., 1998). As a result, turfgrass grown under shade often declines in quality.

Zoysiagrass is a sod-forming warm-season perennial turfgrass indigenous to the Pacific Rim (Anderson, 2000). There are 11 species in the Zoysia genus, of which three are used as a turfgrass: Z. japonica, Z. matrella, and Z. pacifica (Engelke and Anderson, 2003). In the United States, zoysiagrass is used extensively on golf courses and home lawns

Received for publication 16 July 2014. Accepted for publication 24 Sept. 2014.

We thank the Heart of America Golf Course Superintendents Association and the Kansas Turfgrass Foundation for grant support.

Contribution no. 14-116-J from the Kansas Agricultural Experiment Station.

${ }^{1}$ Former Graduate Research Assistant.

${ }^{2}$ To whom reprint requests should be addressed; e-mail jfry@ksu.edu. throughout the transition zone. The lower input requirements of zoysiagrass compared with other available turfgrasses make it a desirable choice for use as a turfgrass in this region (Fry and Huang, 2004).

Zoysiagrasses vary in shade tolerance. In general, Z. matrella cultivars and 'Emerald' are considered more shade-tolerant than $Z$. japonica cultivars (Fry and Huang, 2004; Okeyo et al., 2011a; Sladek et al., 2009; Wherley et al., 2011). 'Meyer' has been the primary zoysiagrass used in the transition zone since its release in 1951, mainly as a result of its excellent cold-hardiness (Grau and Radko, 1951). However, 'Meyer' performs poorly under moderate to dense shade (Ervin et al., 2002; Riffell et al., 1995; Sladek et al., 2009). This is problematic on golf courses and home lawns with considerable shade. Often, 'Meyer' is replaced with Z. matrella cultivars or 'Emerald', which are less hardy (Fry and Huang, 2004), and can only be used in the southern-most part of the transition zone.

Since 2004, researchers at Kansas State University (Manhattan, KS) and Texas A\&M University (Texas AgriLife Research and Extension Center, Dallas, TX) have collaborated to develop zoysiagrass cultivars with excellent quality and freeze tolerance. In an effort to produce improved zoysiagrasses, researchers crossed lines of (Z. japonica $\times$ $Z$. pacifica) and Z. matrella with $Z$. japonica lines. Their goal was to develop cultivars with excellent density and a fine leaf texture like that of $Z$. matrella but with freezing tolerance equal to or better than that of 'Meyer'. Over 600 progeny from the aforementioned crosses have been evaluated for quality and winter survival at the Rocky Ford Turfgrass Research Center at Manhattan, KS (Fry et al., 2008; Okeyo et al., 2011b). Evaluation of several of these grasses indicated that progeny from (Z. matrella $\times$ $Z$. japonica $)$ and $[(Z$. japonica $\times Z$. pacifica $) \times$ $Z$. japonica] exhibited superior stolon production under natural shade compared with 'Meyer' (Okeyo et al., 2011a) and have a freezing tolerance equal to that of 'Meyer' (Okeyo et al., 2011b).

The long-term shade tolerance of these high-performing progeny has not been evaluated. Identifying genotypes with improved shade tolerance compared with 'Meyer' and characteristics aiding survival under dense shade will help lead to improved zoysiagrasses for the transition zone. This study was conducted to determine changes and differences in growth among selected Zoysia cultivars and progeny under a natural shade environment over a 3-year period in the transition zone.

\section{Materials and Methods}

This experiment was initiated in June 2010 at the Rocky Ford Turfgrass Research Center at Manhattan, KS. Soil type was a Chase silt loam (fine, montmorillonitic, mesic, Aquic, Argiudoll) with pH 5.7, 3.3\% organic matter, $48 \mathrm{mg} \cdot \mathrm{kg}^{-1}$ phosphorus, and $295 \mathrm{mg} \cdot \mathrm{kg}^{-1}$ potassium determined before planting (Soil Testing Laboratory, Kansas State University, Manhattan, KS).

Zoysiagrass was planted as plugs in flats in the greenhouse to establish sod pieces measuring $61 \times 30.5 \mathrm{~cm}$. Sod was planted in the field as $0.37-\mathrm{m}^{2}$ plots on 10 June 2010 . Plots were fertilized at planting with $5 \mathrm{~g} \mathrm{~N} / \mathrm{m}^{2}$ using diammonium phosphate $(18 \mathrm{~N}-20 \mathrm{P}-0 \mathrm{~K})$, maintained at a $7-\mathrm{cm}$ mowing height, and received $5 \mathrm{~g} \mathrm{~N} / \mathrm{m}^{2}$ from urea $(46 \mathrm{~N}-0 \mathrm{P}-0 \mathrm{~K})$ annually in June. Irrigation was applied to prevent severe drought stress.

Seven genotypes were selected for this study: the cultivars Zorro (Z. matrella), Emerald (Z. japonica $\times Z$. pacifica), Meyer (Z. japonica), and Chinese Common ( $Z$. japonica) and the experimental progeny $\operatorname{Exp} 1$ ( $Z$. matrella $\times Z$. japonica), and Exp2 and Exp3 [(Z. japonica $\times$ $Z$. pacifica $) \times Z$. japonica]. The experimental progeny have been previously evaluated and are considered to have good freeze tolerance in Manhattan, KS.

Data collected during the growing season included visual quality, fall color retention, spring green-up, leaf extension rate $\left(\mathrm{mm} \cdot \mathrm{d}^{-1}\right)$, leaf width $(\mathrm{mm})$, tiller density (tillers $/ \mathrm{m}^{-2}$ ), and percentage green cover. Visual turfgrass quality was rated on a 1 to 9 scale $(1=$ poor, $6=$ minimally acceptable, and $9=$ superior). Fall color retention and spring green-up were also visually evaluated on 15 Nov. 2010, 23 May and 31 Oct. 2011, 2 Apr. and 4 Nov. 2012 , on a 1 to 9 scale $(1=$ straw brown, $6=$ minimally acceptable color, and $9=$ dark 
Table 1. Mean turfgrass quality of zoysiagrass genotypes under tree shade that resulted in a 91\% reduction in PAR at Manhattan, KS, in 2010, 2011 , and 2012.

\begin{tabular}{|c|c|c|c|c|c|c|c|c|c|c|c|c|}
\hline & \multicolumn{4}{|c|}{2010} & \multicolumn{4}{|c|}{2011} & \multicolumn{4}{|c|}{2012} \\
\hline & June & July & Aug. & Sept. & June & July & Aug. & Sept. & June & July & Aug. & Sept. \\
\hline $\begin{array}{l}\text { Chinese } \\
\text { Common }\end{array}$ & $7.0 \mathrm{~d}^{\mathrm{x}}$ & $6.8 \mathrm{c}$ & $6.8 \mathrm{~d}$ & $6.6 \mathrm{~b}$ & $6.6 \mathrm{~b}$ & $6.0 \mathrm{bcd}$ & $6.6 \mathrm{bc}$ & $5.8 \mathrm{~cd}$ & $4.0 \mathrm{~d}$ & $3.4 \mathrm{~d}$ & $4.0 \mathrm{c}$ & $3.2 \mathrm{c}$ \\
\hline ‘Emerald’ & $8.4 \mathrm{ab}$ & $7.2 \mathrm{bc}$ & $7.6 a b c$ & $8.0 \mathrm{a}$ & $4.0 \mathrm{~cd}$ & $5.2 \mathrm{de}$ & $6.4 \mathrm{bc}$ & $5.8 \mathrm{~cd}$ & $7.2 \mathrm{abc}$ & $7.4 \mathrm{ab}$ & $8.0 \mathrm{a}$ & $7.0 \mathrm{a}$ \\
\hline ‘Meyer’ & $7.8 \mathrm{bc}$ & $7.4 \mathrm{ab}$ & $7.8 \mathrm{ab}$ & $7.2 \mathrm{~b}$ & $7.0 \mathrm{ab}$ & $6.6 a b c$ & $7.0 \mathrm{abc}$ & $6.8 \mathrm{abc}$ & $6.4 \mathrm{bc}$ & $5.6 \mathrm{c}$ & $5.4 b c$ & $4.4 \mathrm{bc}$ \\
\hline ‘Zorro' & $8.8 \mathrm{a}$ & $7.8 \mathrm{ab}$ & $8.0 \mathrm{a}$ & $8.0 \mathrm{a}$ & $3.4 \mathrm{~d}$ & $4.6 \mathrm{e}$ & $5.8 \mathrm{c}$ & $5.6 \mathrm{~d}$ & $6.2 \mathrm{bc}$ & $6.4 \mathrm{bc}$ & $7.4 \mathrm{a}$ & $7.2 \mathrm{a}$ \\
\hline Exp1 & $8.2 \mathrm{abc}$ & $7.2 \mathrm{bc}$ & $7.2 \mathrm{~cd}$ & $6.8 \mathrm{~b}$ & $4.8 \mathrm{c}$ & $5.6 \mathrm{cde}$ & $6.0 \mathrm{c}$ & $6.2 \mathrm{bcd}$ & $5.8 \mathrm{c}$ & $5.6 \mathrm{c}$ & $6.6 \mathrm{ab}$ & $5.8 \mathrm{ab}$ \\
\hline Overall & 8.1 & 7.3 & 7.5 & 7.4 & 5.7 & 6.1 & 6.8 & 6.4 & 6.5 & 6.3 & 6.6 & 5.9 \\
\hline
\end{tabular}

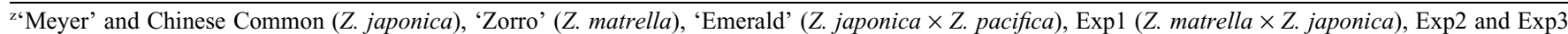
$[(Z$. japonica $\times$ Z. pacifica $) \times Z$. japonica $]$.

${ }^{y}$ Visual zoysiagrass quality was rated on a 1 to 9 scale $(1=$ poor, $6=$ minimally acceptable, $9=$ superior $)$.

${ }^{x}$ Genotype means in the same column followed by a different letter are significantly different based on Fisher's least significant difference at $P<0.05$. Means represent ratings from five replications on one rating date during the month.

$P A R=$ photosynthetically active radiation.

green). Leaf extension rate was determined in each plot by measuring the length of a randomly selected leaf immediately after mowing and then again 5 to $7 \mathrm{~d}$ later. Leaf width was determined by measuring the width of a randomly selected fully developed leaf at its midpoint in each plot on the same day leaf length was measured. Tiller density was determined from three randomly selected $14.85-\mathrm{cm}^{2}$ areas within each plot. Each month, tiller density percentage was normalized to represent the percentage of June 2010 tiller density: [(monthly tiller density/June 2010 tiller density) $\times 100$ ].

Beginning in 2011, a lighted camera box was used to evaluate percentage green cover (Richardson et al., 2001). The lighted camera box contained four compact fluorescent light bulbs (Model CF13EL/MICRO/C/865/BL2; Sylvania, Danvers, MA). Digital images were obtained with a Nikon D5000 (Nikon Corporation, Tokyo, Japan) digital camera mounted on the light box. Camera shutter speed was $1 / 400 \mathrm{~s}$, aperture F4.5, and focal length $26 \mathrm{~mm}$. Digital images were analyzed for percentage green cover using the "Turf Analysis" macro (Karcher and Richardson, 2005) for SigmaScan Pro 5.0 (SPSS, Inc., Chicago, IL) with hue and saturation thresholds of 50 to 107 and 0 to 100 , respectively.

An on-site weather station, positioned in full sun within $100 \mathrm{~m}$ of the study area, recorded average air temperature $2 \mathrm{~m}$ above the ground at hourly intervals and maximum and minimum air temperatures daily. Photosynthetically active radiation was also collected at hourly intervals using a quantum sensor (LI-190; LI-COR, Inc., Lincoln, NE).

Plots were arranged along the shaded (north) side of a mature line of silver maple trees. Photosynthetically active radiation under the shade was measured hourly, for 24-h periods, with an automated ceptometer (AccuPAR LP-80; Decagon Devices, Inc., Pullman, WA) at three locations within the study area on cloud-free days on 10, 13, and 19 Aug. 2012. Full-sun $P A R$ was obtained from the weather station. Photosynthetically active radiation was reduced by $91 \%$ under the tree shade compared with full sun.

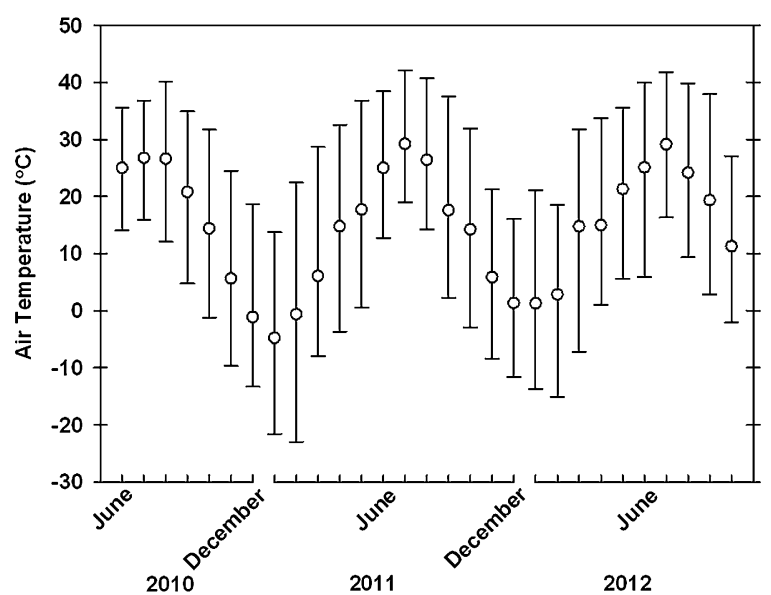

Fig. 1. Monthly mean, maximum, and minimum air temperatures at the study site in Manhattan, KS, from June 2010 through Oct. 2012. Circles represent the mean monthly air temperature. Bars represent the maximum and minimum temperatures for each month.

The experimental design was a randomized complete block with five replications. Zoysiagrass genotype (Chinese Common, 'Emerald', 'Meyer', 'Zorro', Exp1, Exp2, and Exp3) was the single treatment factor. Data were subjected to analysis of variance $(P<$ 0.05 ) using the PROC GLM procedure (SAS Institute Inc., Cary, NC). Where appropriate, means were separated using Fisher's protected least significant difference at $P<0.05$.

\section{Results and Discussion}

Turfgrass quality. In 2010, turfgrass quality was acceptable for all genotypes (Table 1). 'Emerald', 'Zorro', and Exp2 exhibited the highest turfgrass quality on the last rating date, 30 Sept.

In June 2011, 'Emerald' and 'Zorro' had the lowest turfgrass quality ratings (Table 1). Both cultivars are adapted to the southern United States but are not considered winterhardy in Manhattan, KS. During the winter of 2010-11, minimum air temperature was $-13.4,-21.6$, and $-23.0^{\circ} \mathrm{C}$ during the months of Dec. 2010, Jan. 2011, and Feb. 2011, respectively (Fig. 1). Although the experimental progeny had been evaluated for winter-hardiness, Exp1 experienced some winter injury. The stress of growing under the shade may have prevented Exp1 from acclimating fully to cold temperatures, resulting in winter injury. During the summer of 2011, 'Emerald' and 'Zorro' recovered, but quality ratings remained lower than most other genotypes. Exp1 recovered sufficiently to attain minimally acceptable quality by Aug. 2011. Progeny Exp2 and Exp3, and 'Meyer', were the top performers in 2011 with Exp2 consistently having the highest quality ratings.

The winter of 2011-12 was particularly mild (Fig. 1) and no winter injury was observed. 'Emerald' and experimental progeny Exp2 and Exp3 received superior quality ratings throughout the summer of 2012 (Table 1). Chinese Common and 'Meyer' quality declined throughout the summer of 2012. In Aug. 2012, damage resulting from the bluegrass billbug [Sphenophorus parvulus (Gyllenhal)] was observed. The damage was most notable on Exp2 and 'Meyer', causing their quality to decline from July to August, whereas the quality of the other grasses stayed relatively the same or increased. However, by the end of the summer, experimental progeny 
Exp2 and Exp3 and the cultivars Emerald and Zorro all had quality ratings higher than the minimally acceptable level of 6.0.

Two reports contain information on zoysiagrass performance under tree shade (Riffell et al., 1995; Wherley et al., 2011). Riffell et al. (1995) found 'Meyer' to be one of the poorest performers under tree shade, whereas 'Emerald' maintained good quality. In our study, 'Emerald' showed an overall increase in visual quality from June to August during the 2011 and 2012 growing seasons, whereas the visual quality of 'Meyer' showed a general decline in visual quality during the same period. The resource use (such as carbohydrate use or photosynthetic capacity) of 'Emerald' may be superior to that of 'Meyer', allowing it to persist for longer periods under dense shade. Wherley et al. (2011) concluded that Z. matrella genotypes including 'Shadow Turf', 'Zeon', 'Zorro', 'Cavalier', 'Royal', and 'Diamond' were better adapted than $Z$. japonica types, like 'Meyer', under $89 \%$ tree shade. The aforementioned studies (Riffell et al., 1995; Wherley et al., 2011) were conducted in Dallas, TX, which has a climate much different from our study site. The extended growing season and milder winters of the southern United States would likely result in differences in turf performance compared with evaluations in Manhattan, KS.

Tiller density. No differences were observed among genotypes for tiller density in 2010 (Table 2). The Aug. 2010 tiller density change shows that no genotype declined more than $15 \%$ before the onset of fall.

Tiller density decreased markedly from Sept. 2010 to June 2011 (Table 2). As discussed previously, the winter of 2010-11 was very cold and winter injury was observed on 'Emerald', 'Zorro', and Exp1. The cold temperatures and shade stress may have created an interaction resulting in some of the genotypes being less acclimated to the cold temperatures than they would otherwise have been in full sun. Progeny Exp2 exhibited a decline in tiller density of $8 \%$, whereas that of all other genotypes declined $17 \%$ to $62 \%$. However, tiller density increased in all genotypes except Chinese Common from June 2011 to Aug. 2011. This shows that zoysiagrass has the potential to recuperate during summer months from winter injury, even when $P A R$ is reduced by more than $90 \%$. Experimental progeny Exp2 and 'Meyer' had the highest tiller densities of 90 and $76 \%$, respectively, by Aug. 2011.

The winter of 2011-12 was milder with a warmer spring than the previous year (Fig. 1).
Most genotypes exhibited their highest tiller densities of 2012 earlier in the summer than in 2011 (Table 2). Experimental progeny Exp2, Exp3, and 'Emerald' had the highest tiller density in June 2012.

Okeyo et al. (2011a) also evaluated tillering of zoysiagrass progeny originating from the same parents as the experimentals evaluated here. In their experiment, tillering was evaluated in $6-\mathrm{cm}$ diameter plugs between June and the end of September. Over this period, none of the experimental grasses gained or lost tillers any differently than 'Meyer'. By evaluating progeny of the same parents in larger plots in this study, we were able to demonstrate that tiller density of either Exp2 and Exp3, both of which are progeny from $[(Z$. japonica $\times Z$. pacifica $) \times Z$. japonica], was superior to 'Meyer' on one or more dates in the second and third growing seasons after sodding.

Leaf extension rate. Overall, leaf extension rate reached its maximum during early to midsummer each year (Table 3). Chinese Common consistently had the highest leaf extension rate and exhibited the largest decline in quality and tiller density throughout the season each year.

An increased leaf extension rate is often observed under shade as a result of increased

Table 2. Tiller density of zoysiagrass genotypes under tree shade that resulted in a 91\% reduction in $P A R$ at Manhattan, KS, in 2010,2011 , and 2012.

\begin{tabular}{|c|c|c|c|c|c|c|c|c|c|c|c|}
\hline \multirow[b]{3}{*}{ Genotype $^{z}$} & \multicolumn{3}{|c|}{2010} & \multicolumn{4}{|c|}{2011} & \multicolumn{4}{|c|}{2012} \\
\hline & July & Aug. & Sept. & June & July & Aug. & Sept. & June & July & Aug. & Sept. \\
\hline & \multicolumn{11}{|c|}{ - } \\
\hline Chinese Common & $87 \mathrm{NS}$ & $86 \mathrm{NS}$ & $80 \mathrm{NS}$ & $63 \mathrm{a}^{\mathrm{x}}$ & $44 \mathrm{~b}$ & $56 \mathrm{bc}$ & $39 \mathrm{NS}$ & $40 \mathrm{c}$ & $43 \mathrm{~d}$ & $27 \mathrm{c}$ & $19 \mathrm{c}$ \\
\hline 'Emerald' & 89 & 96 & 80 & $18 \mathrm{c}$ & $35 \mathrm{~b}$ & $58 \mathrm{bc}$ & 40 & $72 \mathrm{ab}$ & $78 \mathrm{a}$ & $64 \mathrm{ab}$ & $45 \mathrm{ab}$ \\
\hline 'Meyer' & 109 & 109 & 78 & $45 \mathrm{~b}$ & $48 \mathrm{ab}$ & $76 \mathrm{ab}$ & 46 & $53 \mathrm{bc}$ & $44 \mathrm{~cd}$ & $44 \mathrm{bc}$ & $32 \mathrm{abc}$ \\
\hline 'Zorro' & 78 & 94 & 78 & $21 \mathrm{c}$ & $31 \mathrm{~b}$ & $40 \mathrm{c}$ & 40 & $41 \mathrm{c}$ & $51 \mathrm{bcd}$ & $66 \mathrm{ab}$ & $47 \mathrm{a}$ \\
\hline Exp1 & 92 & 88 & 71 & $28 \mathrm{c}$ & $36 \mathrm{~b}$ & $43 \mathrm{c}$ & 27 & $46 \mathrm{bc}$ & $40 \mathrm{~d}$ & $46 \mathrm{bc}$ & $30 \mathrm{bc}$ \\
\hline Exp2 & 109 & 105 & 78 & $70 \mathrm{a}$ & $69 \mathrm{a}$ & $90 \mathrm{a}$ & 65 & 99 a & $68 \mathrm{abc}$ & $58 \mathrm{ab}$ & $34 \mathrm{abc}$ \\
\hline Exp3 & 90 & 85 & 76 & $47 \mathrm{~b}$ & $45 \mathrm{~b}$ & $61 \mathrm{bc}$ & 49 & $73 \mathrm{ab}$ & $75 \mathrm{ab}$ & $70 \mathrm{a}$ & $44 \mathrm{ab}$ \\
\hline Overall mean & 93 & 95 & 77 & 42 & 44 & 60 & 43 & 61 & 57 & 54 & 36 \\
\hline
\end{tabular}

z'Meyer' and Chinese Common (Z. japonica), 'Zorro' (Z. matrella), 'Emerald' (Z. japonica $\times$ Z. pacifica), Exp1 (Z. matrella $\times$ Z. japonica), Exp2 and Exp3 $[(Z$. japonica $\times$ Z. pacifica $) \times Z$. japonica $]$.

${ }^{y}$ Tiller density was adjusted to represent the percentage of June 2010: [(monthly tiller density/June 2010 tiller density) $\left.\times 100\right]$.

${ }^{x}$ Genotype means in the same column followed by a different letter are significantly different based on Fisher's least significant difference at $P<0.05$. Means represent ratings from five replications on one rating date during the month.

$P A R=$ photosynthetically active radiation.

NS $=$ means were non-statistically different.

Table 3. Leaf extension rates for zoysiagrass genotypes under tree shade that resulted in a $91 \%$ reduction in $P A R$ at Manhattan, KS, in 2010,2011 , and 2012.

\begin{tabular}{|c|c|c|c|c|c|c|c|c|c|c|}
\hline \multirow[b]{3}{*}{ Genotype $^{z}$} & \multicolumn{3}{|c|}{2010} & \multicolumn{4}{|c|}{2011} & \multicolumn{3}{|c|}{2012} \\
\hline & July & Aug. & Sept. & June & July & Aug. & Sept. & June & July & Aug. \\
\hline & --------- & --------- & --.-- & ------- & extensio & $(\mathrm{mm} \cdot \mathrm{d}$ & ------. & ----- & ----- & ------ \\
\hline Chinese Common & $11.5 \mathrm{a}^{\mathrm{x}}$ & $6.5 \mathrm{a}$ & $1.8 \mathrm{NS}$ & $7.4 \mathrm{a}$ & $5.0 \mathrm{a}$ & $2.3 \mathrm{NS}$ & $2.9 \mathrm{a}$ & $8.1 \mathrm{NS}$ & $6.0 \mathrm{NS}$ & $2.7 \mathrm{Ns}$ \\
\hline 'Emerald' & $2.5 \mathrm{~d}$ & $1.5 \mathrm{c}$ & 0.5 & $2.0 \mathrm{c}$ & $1.5 \mathrm{~b}$ & 1.2 & $1.1 \mathrm{~b}$ & 3.7 & 4.5 & 2.0 \\
\hline 'Meyer' & $9.2 \mathrm{~b}$ & $4.3 \mathrm{abc}$ & 1.4 & $2.8 \mathrm{bc}$ & $3.0 \mathrm{ab}$ & 1.7 & $0.9 \mathrm{~b}$ & 4.7 & 3.8 & 2.6 \\
\hline 'Zorro' & $6.3 \mathrm{c}$ & $3.3 \mathrm{bc}$ & 2.0 & $3.0 \mathrm{bc}$ & $1.3 \mathrm{~b}$ & 2.2 & $1.4 \mathrm{ab}$ & 5.3 & 5.8 & 2.0 \\
\hline Exp1 & $8.7 \mathrm{~b}$ & $3.8 \mathrm{abc}$ & 0.9 & $5.2 \mathrm{ab}$ & $5.3 \mathrm{a}$ & 3.5 & $1.7 \mathrm{ab}$ & 6.6 & 7.0 & 2.6 \\
\hline Exp2 & $7.3 \mathrm{bc}$ & $5.8 \mathrm{ab}$ & 1.8 & $4.2 \mathrm{bc}$ & $5.3 \mathrm{a}$ & 2.0 & $2.7 \mathrm{a}$ & 7.3 & 6.0 & 2.8 \\
\hline Exp3 & $6.5 \mathrm{c}$ & $4.0 \mathrm{abc}$ & 0.9 & $5.2 \mathrm{ab}$ & $4.3 \mathrm{a}$ & 3.0 & $2.7 \mathrm{a}$ & 6.9 & 5.8 & 2.6 \\
\hline Overall mean & 7.4 & 4.1 & 1.3 & 4.3 & 3.7 & 2.3 & 1.9 & 6.1 & 5.5 & 2.4 \\
\hline
\end{tabular}

z'Meyer' and Chinese Common (Z. japonica), 'Zorro' (Z. matrella), 'Emerald' (Z. japonica $\times$ Z. pacifica), Exp1 (Z. matrella $\times$ Z. japonica), Exp2 and Exp3 $[(Z$. japonica $\times Z$. pacifica $) \times Z$. japonica $]$.

yLeaf extension rate was determined by measuring leaf length immediately after mowing and 5 to $7 \mathrm{~d}$ later.

${ }^{\mathrm{x}}$ Genotype means in the same column followed by a different letter are significantly different based on Fisher's least significant difference at $P<0.05$. Means represent ratings from five replications on one rating date during the month.

$P A R=$ photosynthetically active radiation.

NS $=$ means were non-statistically different. 
levels of bioactive gibberellin (Qian et al., 1998; Qian and Engelke, 1997, 1999; Reid et al., 2010; Wherley et al., 2011). In a shaded environment, plant carbohydrate levels are already low (Bell and Danneberger, 1999; Burton et al., 1959; Qian et al., 1998), and energy used for leaf extension may prove detrimental to the turfgrass stand. Wherley et al. (2011) observed that the zoysiagrass cultivars that performed best under shade had the slowest leaf extension rate. This is in contrast to our study where Exp2 and Exp3 often had high leaf extension rates but were top performers.

Leaf width. 'Zorro' and 'Emerald' consistently had the narrowest leaf blades, whereas Chinese Common and 'Meyer' had the widest (Table 4). For unknown reasons, leaf width across genotypes increased 0.3 to 1.4 $\mathrm{mm}$ from Sept. 2010 to June 2011. However, this was not observed from Sept. 2011 to June 2012.

Leaf width is the defining characteristic of turfgrass texture. In general, Z. japonica genotypes have a coarser texture than the more desired finer texture of $Z$. matrella and $Z$. pacifica genotypes (Anderson, 2000; Fry et al., 2008). Chinese Common and 'Meyer' consistently had the largest leaf width. The experimental progeny were often intermediate to the coarser $Z$. japonica types and finer 'Zorro' and 'Emerald'.

Leaf width has been reported to decrease in turfgrass grown under shade (Wilkinson and Beard, 1974; Winstead and Ward, 1974), which may be the result of cell elongation

Table 4. Leaf width for zoysiagrass genotypes under tree shade that resulted in a $91 \%$ reduction in $P A R$ at Manhattan, KS in 2010,2011 , and 2012.

\begin{tabular}{|c|c|c|c|c|c|c|c|c|c|c|}
\hline \multirow[b]{3}{*}{ Genotype $^{z}$} & \multicolumn{3}{|c|}{2010} & \multicolumn{4}{|c|}{2011} & \multicolumn{3}{|c|}{2012} \\
\hline & July & Aug. & Sept. & June & July & Aug. & Sept. & June & July & Aug. \\
\hline & ----- & - & & & Leaf & $(\mathrm{mm})^{\mathrm{y}}$ & & & & \\
\hline Chinese Common & $3.3 \mathrm{a}^{\mathrm{x}}$ & $3.5 \mathrm{a}$ & $3.0 \mathrm{a}$ & $4.4 \mathrm{a}$ & $4.2 \mathrm{a}$ & $3.8 \mathrm{a}$ & $4.0 \mathrm{a}$ & $3.6 \mathrm{a}$ & $3.6 \mathrm{a}$ & $3.2 \mathrm{a}$ \\
\hline 'Emerald' & $1.8 \mathrm{de}$ & $1.8 \mathrm{c}$ & $1.7 \mathrm{c}$ & $2.0 \mathrm{~d}$ & $1.8 \mathrm{~d}$ & $1.9 \mathrm{~cd}$ & $1.9 \mathrm{e}$ & $2.1 \mathrm{~cd}$ & $2.1 \mathrm{~cd}$ & $1.9 \mathrm{~cd}$ \\
\hline 'Meyer' & $2.6 \mathrm{~b}$ & $2.4 \mathrm{~b}$ & $2.5 \mathrm{~b}$ & $3.2 \mathrm{~b}$ & $3.0 \mathrm{~b}$ & $3.0 \mathrm{~b}$ & $2.9 \mathrm{~b}$ & $3.3 \mathrm{a}$ & $3.1 \mathrm{~b}$ & $2.8 \mathrm{ab}$ \\
\hline ‘Zorro’' & $1.7 \mathrm{e}$ & $1.7 \mathrm{c}$ & $1.6 \mathrm{c}$ & $2.0 \mathrm{~d}$ & $1.9 \mathrm{~d}$ & $1.7 \mathrm{~d}$ & $1.8 \mathrm{e}$ & $1.9 \mathrm{~d}$ & $1.7 \mathrm{e}$ & $1.7 \mathrm{~d}$ \\
\hline Exp1 & $2.2 \mathrm{bcd}$ & $2.2 \mathrm{bc}$ & $2.4 \mathrm{~b}$ & $3.0 \mathrm{bc}$ & $2.5 \mathrm{c}$ & $2.2 \mathrm{~cd}$ & $2.6 \mathrm{bc}$ & $2.5 \mathrm{bc}$ & $2.4 \mathrm{~cd}$ & $2.5 \mathrm{~b}$ \\
\hline Exp2 & $2.3 \mathrm{bc}$ & $2.0 \mathrm{bc}$ & $2.2 \mathrm{~b}$ & $2.7 \mathrm{c}$ & $2.5 \mathrm{c}$ & $2.0 \mathrm{~cd}$ & $2.2 \mathrm{de}$ & $2.5 \mathrm{bc}$ & $2.4 \mathrm{~cd}$ & $2.3 \mathrm{bc}$ \\
\hline Exp3 & $2.2 \mathrm{~cd}$ & $2.2 \mathrm{bc}$ & $2.2 \mathrm{~b}$ & $2.8 \mathrm{bc}$ & $2.6 \mathrm{c}$ & $2.4 \mathrm{c}$ & $2.5 \mathrm{~cd}$ & $2.6 \mathrm{~b}$ & $2.4 \mathrm{~cd}$ & $2.4 \mathrm{~b}$ \\
\hline Overall mean & 2.3 & 2.3 & 2.2 & 2.8 & 2.7 & 2.4 & 2.5 & 2.6 & 2.5 & 2.4 \\
\hline
\end{tabular}

z‘Meyer' and Chinese Common (Z. japonica), 'Zorro' (Z. matrella), 'Emerald' (Z. japonica $\times$ Z. pacifica), Exp1 (Z. matrella $\times$ Z. japonica), Exp2 and Exp3 $[(Z$. japonica $\times Z$. pacifica $) \times Z$. japonica $]$.

${ }^{y}$ Leaf width was determined by measuring the width of fully developed leaves at its midpoint.

${ }^{\mathrm{x}}$ Genotype means in the same column followed by a different letter are significantly different based on Fisher's least significant difference at $P<0.05$. Means represent ratings from five replications on one rating date during the month.

$P A R=$ photosynthetically active radiation.

Table 5. Percentage green cover of zoysiagrass genotypes under tree shade that resulted in a $91 \%$ reduction in $P A R$ at Manhattan, KS, in 2011 and 2012.

\begin{tabular}{|c|c|c|c|c|c|c|c|c|c|c|c|c|}
\hline \multirow[b]{3}{*}{ Genotype ${ }^{z}$} & \multicolumn{6}{|c|}{2011} & \multicolumn{6}{|c|}{2012} \\
\hline & May & June & July & Aug. & Sept. & Oct. & Apr. & June & July & Aug. & Sept. & Nov. \\
\hline & \multicolumn{12}{|c|}{--1-10 } \\
\hline Chinese Common & $53 \mathrm{a}^{\mathrm{x}}$ & $69 \mathrm{~b}$ & $64 \mathrm{bcd}$ & $61 \mathrm{c}$ & $36 \mathrm{~d}$ & $4 \mathrm{~d}$ & $20 \mathrm{bcd}$ & $50 \mathrm{~b}$ & $42 \mathrm{c}$ & $47 \mathrm{c}$ & $46 \mathrm{~b}$ & $7 \mathrm{c}$ \\
\hline 'Emerald' & $7 \mathrm{~d}$ & $37 \mathrm{c}$ & $50 \mathrm{de}$ & $57 \mathrm{c}$ & $49 \mathrm{bc}$ & $20 \mathrm{~b}$ & $16 \mathrm{~cd}$ & $87 \mathrm{a}$ & $83 \mathrm{a}$ & $81 \mathrm{a}$ & $71 \mathrm{a}$ & $32 \mathrm{a}$ \\
\hline 'Meyer' & $47 \mathrm{a}$ & $69 \mathrm{~b}$ & $72 \mathrm{bc}$ & $76 \mathrm{ab}$ & $45 \mathrm{~cd}$ & $6 \mathrm{~d}$ & $27 \mathrm{ab}$ & $75 \mathrm{a}$ & $64 \mathrm{~b}$ & $60 \mathrm{~b}$ & $47 \mathrm{~b}$ & $5 \mathrm{c}$ \\
\hline 'Zorro' & $4 d$ & $35 \mathrm{c}$ & $48 \mathrm{e}$ & $64 \mathrm{bc}$ & $59 \mathrm{ab}$ & $30 a$ & $12 \mathrm{~d}$ & $85 \mathrm{a}$ & $82 \mathrm{a}$ & $82 \mathrm{a}$ & $77 \mathrm{a}$ & $37 \mathrm{a}$ \\
\hline Exp1 & $18 \mathrm{c}$ & $47 \mathrm{c}$ & 57 cde & $63 \mathrm{bc}$ & $46 \mathrm{~cd}$ & $15 \mathrm{bc}$ & $15 \mathrm{~cd}$ & $78 \mathrm{a}$ & $68 \mathrm{ab}$ & $65 \mathrm{~b}$ & $58 \mathrm{~b}$ & $14 \mathrm{~b}$ \\
\hline Exp2 & $52 \mathrm{a}$ & $87 \mathrm{a}$ & $89 \mathrm{a}$ & $85 \mathrm{a}$ & $71 \mathrm{a}$ & $14 \mathrm{bc}$ & $33 \mathrm{a}$ & $93 \mathrm{a}$ & $81 \mathrm{a}$ & $66 \mathrm{~b}$ & $53 \mathrm{~b}$ & $9 \mathrm{bc}$ \\
\hline Exp3 & $36 \mathrm{~b}$ & $66 \mathrm{~b}$ & $74 \mathrm{ab}$ & $78 \mathrm{ab}$ & $54 \mathrm{bc}$ & $9 \mathrm{~cd}$ & $23 \mathrm{bc}$ & $86 a$ & $81 \mathrm{a}$ & $72 \mathrm{ab}$ & $56 \mathrm{~b}$ & $6 \mathrm{c}$ \\
\hline Overall mean & 31 & 58 & 65 & 69 & 51 & 14 & 21 & 79 & 72 & 68 & 58 & 16 \\
\hline
\end{tabular}

z‘Meyer' and Chinese Common (Z. japonica), 'Zorro' (Z. matrella), 'Emerald' (Z. japonica $\times$ Z. pacifica), Exp1 (Z. matrella $\times$ Z. japonica), Exp2 and Exp3 $[(Z$. japonica $\times Z$. pacifica $) \times Z$. japonica $]$.

yPercent green cover was determined from digital image analysis (Richardson et al., 2001).

${ }^{x}$ Genotype means in the same column followed by a different letter are significantly different based on Fisher's least significant difference at $P<0.05$. Means represent ratings from five replications on one rating date during the month.

$P A R=$ photosynthetically active radiation.

Table 6. Fall and spring color ratings for zoysiagrass genotypes under tree shade that resulted in a $91 \%$ reduction in $P A R$ at Manhattan, KS, in 2010, 2011, and 2012.

\begin{tabular}{|c|c|c|c|c|c|}
\hline \multirow[b]{2}{*}{ Genotype $^{z}$} & 15 Nov. 2010 & 31 Oct. 2011 & 4 Nov. 2012 & 23 May 2011 & 2 Apr. 2012 \\
\hline & \multicolumn{3}{|c|}{ 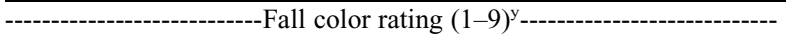 } & \multicolumn{2}{|c|}{---------Spring color rating $(1-9)^{\mathrm{x}}$-------- } \\
\hline Chinese Common & $3.2 \mathrm{e}^{\mathrm{w}}$ & $1.2 \mathrm{~d}$ & $1.2 \mathrm{~d}$ & $8.0 \mathrm{a}$ & $5.6 \mathrm{ab}$ \\
\hline 'Emerald' & $6.4 \mathrm{a}$ & $5.6 \mathrm{a}$ & $6.0 \mathrm{a}$ & $2.6 \mathrm{~cd}$ & $3.4 \mathrm{c}$ \\
\hline 'Meyer' & $3.6 \mathrm{de}$ & $2.4 \mathrm{~cd}$ & $2.0 \mathrm{bcd}$ & $7.2 \mathrm{ab}$ & $6.4 \mathrm{a}$ \\
\hline ‘Zorro’' & $7.2 \mathrm{a}$ & $6.4 \mathrm{a}$ & $6.6 \mathrm{a}$ & $1.2 \mathrm{~d}$ & $1.8 \mathrm{~d}$ \\
\hline Exp1 & $5.0 \mathrm{bc}$ & $3.4 \mathrm{bc}$ & $2.8 \mathrm{~b}$ & $3.6 \mathrm{c}$ & $2.8 \mathrm{~cd}$ \\
\hline Exp2 & $5.4 \mathrm{~b}$ & $4.0 \mathrm{~b}$ & $2.4 \mathrm{bc}$ & $7.2 \mathrm{ab}$ & $5.8 \mathrm{a}$ \\
\hline Exp3 & $4.2 \mathrm{~cd}$ & $4.0 \mathrm{~b}$ & $1.6 \mathrm{~cd}$ & $5.8 \mathrm{~b}$ & $4.2 \mathrm{bc}$ \\
\hline Overall mean & 5.0 & 3.9 & 3.2 & 5.1 & 4.3 \\
\hline
\end{tabular}

${ }^{z ' M e y e r ' ~ a n d ~ C h i n e s e ~ C o m m o n ~(Z . ~ j a p o n i c a), ~ ' Z o r r o ' ~(Z . ~ m a t r e l l a), ~ ' E m e r a l d ' ~(Z . ~ j a p o n i c a ~} \times$ Z. pacifica), Exp1 (Z. matrella $\times$ Z. japonica), Exp2 and Exp3 $[(Z$. japonica $\times Z$. pacifica $) \times Z$. japonica $]$.

${ }^{\text {y } F a l l ~ c o l o r ~ w a s ~ r a t e d ~ o n ~ a ~} 1$ to 9 scale $(1=$ straw brown, $6=$ minimally acceptable color, and $9=$ dark green).

${ }^{\mathrm{x}}$ Spring green-up was rated on a 1 to 9 scale $(1=$ straw brown, $6=$ minimally acceptable color, and $9=$ dark green $)$.

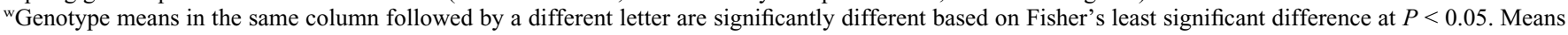
represent ratings from five replications on one rating date during the month.

$P A R=$ photosynthetically active radiation. 
preventing the widening of the leaf blade. In this study, the overall mean leaf width for each month generally declined during each growing season. However, a decline was not observed for each genotype. Tree shade filters most of the red portion of the spectrum out of the light penetrating the canopy (Bell et al., 2000) causing a lower red to far-red light ratio than in full sun. This altered red to far-red light ratio could result in plant morphological changes, including decreased leaf width and increased leaf elongation.

Percentage green cover. Differences among genotypes were observed on all dates (Table 5). Percentage green cover was highest during late summer in 2011 and early summer in 2012, which may have been the result of warmer spring temperatures in 2012 than in 2011.

Chinese Common, 'Meyer', and Exp2 had the highest green cover in May 2011, whereas 'Meyer' and Exp2 the highest cover in Apr. 2012 (Table 5). The southern-adapted genotype 'Zorro' had the highest green cover in Oct. 2011, and 'Emerald' and 'Zorro' had the highest cover in Nov. 2012. The superior adaptation to shade is seen with 'Emerald' and 'Zorro' because they performed well in shade when winter injury was not observed. However, experimental progeny Exp2 and Exp3 both exhibited high percent coverage through much of the study indicating that they possess excellent shade tolerance characteristics. In an earlier study at the same site used here, plugs of zoysiagrass progeny designated as $Z$. matrella $\times Z$. japonica and (Z. japonica $\times Z$. pacifica $) \times Z$. japonica produced more and longer stolons than plugs of 'Meyer' under shade (Okeyo et al., 2011a). Capability to produce stolons under dense shade may also have contributed to the ability of these zoysiagrasses to maintain green coverage in shade as observed here.

Trappe et al. (2011) evaluated several zoysiagrass cultivars under $49 \%$ artificial shade in the field at Fayetteville, AR, and observed that 'Meyer', 'Zorro', and 'Diamond' (Z. matrella) had greater than $90 \%$ coverage after 2 years. In our study, only Exp2 exceeded $90 \%$ green coverage during the 2 years of green coverage evaluation; the difference between the studies may be the result of a greater reduction in $P A R$ herein. Lower light quality may also have contributed to less green coverage in our study, because tree leaves filter the photosynthetically important red and blue wavelengths before they reach the turfgrass surface. 'Meyer', which is typically considered shade-intolerant, may not have been affected by the $49 \%$ shade; therefore, green coverage would only decline in response to greater reductions in PAR. Trappe et al. (2011) also maintained their plots at a much lower cutting height $(1.3 \mathrm{~cm})$ than in our study $(7 \mathrm{~cm})$.

Fall color. Persistent fall green color is a desirable characteristic in zoysiagrasses if winter-hardiness is not compromised. 'Emerald' and 'Zorro' had the highest color ratings on each date (Table 6). Both are southernadapted zoysiagrasses and are not winterhardy at the study site. In Missouri, winter injury occurred on southern-adapted zoysiagrass genotypes, but not 'Meyer', when fall green color was enhanced by late fall fertilization (Dunn et al., 1993), The persistent fall color of 'Emerald' and 'Zorro' is often associated with their vulnerability to winter injury (Fry and Huang, 2004; Okeyo et al., 2011b).

Spring color. Chinese Common, 'Meyer', and Exp2 exhibited the highest spring color rating in both years (Table 6). Greening-up earlier than the other genotypes may allow the turf to use higher irradiance because the tree canopy may not be fully enclosed.

\section{Conclusion}

Zoysiagrass use throughout the transition zone has been limited by adaptation to cold temperatures and shade tolerance. The coldtolerant genotypes, 'Meyer' and Chinese Common, both exhibited declining turfgrass quality and density during the course of the study. The shade-tolerant southern adapted cultivars, Emerald and Zorro, both performed well but exhibited injury after the cold winter of 2010-11. Exp2 and Exp3, the [(Z. japonica $\times$ $Z$. pacifica) $\times Z$. japonica] experimental progeny in this study, had improved shade tolerance compared with 'Meyer' and, along with their equivalent cold tolerance to 'Meyer', could provide transition zone turf managers improved zoysiagrass cultivars in the future.

\section{Literature Cited}

Anderson, S. 2000. Taxonomy of Zoysia (Poaceae): Morphological and molecular variation. $\mathrm{PhD}$ diss., Texas A\&M University, College Station, TX.

Atkinson, J.L., L.B. McCarty, H. Liu, J. Faust, and J.E. Toler. 2012. Diamond zoysiagrass golf green response to reduced light environments with the use of trinexapac-ethyl. Agron. J. 104:847-852.

Beard, J.B. 1973. Turfgrass: Science and culture. Prentice Hall, Englewood Cliffs, NJ.

Beard, J.B. 1997. Shade stress and adaptation mechanisms of turfgrasses. Intl. Turfgrass Soc. Res. J. 8:1186-1195.

Bell, G.E. and T.K. Danneberger. 1999. Temporal shade on creeping bentgrass turf. Crop Sci. 39:1142-1146.

Bell, G.E., T.K. Danneberger, and M.J. McMahon. 2000. Spectral irradiance available for turfgrass growth in sun and shade. Crop Sci. 40:189-195.

Burton, G.W., J.E. Jackson, and F.E. Knox. 1959. The influence of light reduction upon the production, persistence and chemical composition of Coastal bermudagrass, Cynodon dactylon. Agron. J. 51:537-542.

Dudeck, A.E. and C.H. Peacock. 1992. Shade and turfgrass culture, p. 269-284. In: Waddington, D.V., R.N. Carrow, and R.C. Shearman (eds.). Turfgrass. ASA Monogr. 32. ASA,CSSA, SSSA, Madison, WI.

Dunn, J.H., D.D. Minner, B.F. Fresenburg, and S.S. Bughrara. 1993. Fall fertilization of zoysiagrass. Intl. Turfgrass Soc. Res. J. 7:565-571.

Engelke, M.C. and S. Anderson. 2003. Zoysiagrasses (Zoysia spp.), p. 271-285. In: Casler,
M.D. and R.R. Duncan (eds.). Turfgrass biology, genetics, and breeding. John Wiley \& Sons, Hoboken, NJ.

Ervin, E.H., C.H. Ok, B.S. Fresenburg, and J.H. Dunn. 2002. Trinexapac-ethyl restricts shoot growth and prolongs stand density of 'Meyer' zoysiagrass fairway under shade. HortScience 37:502-505.

Fry, J.D. and B. Huang. 2004. Applied turfgrass science and physiology. John Wiley \& Sons, Hoboken, NJ.

Fry, J.D., Q. Zhang, D. Okeyo, M. Engelke, and D. Genovesi. 2008. Improved Zoysia cultivar could have use in transition zone. TurfGrass Trends, Golfdom, Cleveland, OH. p. 58, 60-61.

Grau, F.V. and A.M. Radko. 1951. 'Meyer' (Z-52) Zoysia. USGA J. Turf Mgt. 4:30-31.

Karcher, D.E. and M.D. Richardson. 2005. Batch analysis of digital images to evaluate turfgrass characteristics. Crop Sci. 45:1536-1539.

Okeyo, D.O., J.D. Fry, D.J. Bremer, A. Chandra, A.D. Genovesi, and M.C. Engelke. 2011a Stolon growth and tillering of experimental zoysiagrasses in shade. HortScience 46:14181422.

Okeyo, D.O., J.D. Fry, D. Bremer, C.B. Rajashekar, M. Kennelly, A. Chandra, D.A. Genovesi, and M.C. Engelke. 2011b. Freezing tolerance and seasonal color of experimental zoysiagrasses. Crop Sci. 51:2858-2863.

Qian, Y.L. and M.C. Engelke. 1997. Evaluation of zoysiagrass genotypes for shade tolerance. Texas Turfgrass Res. Rpt. 97:1-11.

Qian, Y.L. and M.C. Engelke. 1999. Influence of trinexapac-ethyl on Diamond zoysiagrass in a shade environment. Crop Sci. 39:202-208.

Qian, Y.L., M.C. Engelke, M.J.V. Foster, and S. Reynolds. 1998. Trinexapac-ethyl restricts shoot growth and improves quality of 'Diamond' zoysiagrass under shade. HortScience 33:10191022.

Reid, J.B., G.M. Symons, and J.J. Ross. 2010. Regulation of gibberellin and brassinosteroid pathways by genetic, environmental and hormonal factors, p. 179-203. In: Davies, P.J. (ed.). Plant hormones: Biosynthesis, signal transduction, action! 3rd Ed. Springer, Dordrecht, The Netherlands.

Richardson, M.D., D.E. Karcher, and L.C. Purcell. 2001. Quantifying turfgrass cover using digital image analysis. Crop Sci. 41:1884-1888.

Riffell, S.K., M.C. Engelke, and S.J. Morton. 1995. Performance of three warm-season turfgrasses cultured in shade: Zoysiagrass. Texas Turfgrass Res. Rpt. 95:60-65.

Sladek, B.S., G.M. Henry, and D.L. Auld. 2009. Evaluation of zoysiagrass genotypes for shade tolerance. HortScience 44:1447-1451.

Trappe, J.M., D.E. Karcher, M.D. Richardson, and A.J. Patton. 2011. Shade and traffic tolerance varies for bermudagrass and zoysiagrass cultivars. Crop Sci. 51:870-877.

Wherley, B.G., P. Skulkaew, A. Chandra, A.D. Genovesi, and M.C. Engelke. 2011. Low-input performance of zoysiagrass (Zoysia spp.) cultivars maintained under dense tree shade. HortScience 46:1033-1037.

Wilkinson, J.F. and J.B. Beard. 1974. Morphological responses of Poa pratensis and Festuca rubra to reduced light intensity. Intl. Turfgrass Soc. Res. J. 2:231-240.

Winstead, C.W. and C.Y. Ward. 1974. Persistence of southern turfgrasses in a shade environment. Intl. Turfgrass Soc. Res. J. 2:221-230. 